\title{
A Cross Industry Comparison of Customer Satisfaction: Do More Alternatives Mean More Satisfaction?
}

\author{
Sulaiman Olanrewaju Adebayo ${ }^{1} \&$ Tosin Tunrayo Olonisakin ${ }^{1}$ \\ ${ }^{1}$ Department of Psychology, Ekiti State University, Ado-Ekiti, Nigeria \\ Correspondence: Sulaiman Olanrewaju Adebayo, Department of Psychology, Ekiti State University, Ado-Ekiti, \\ Nigeria. Tel: 23-480-3386-5790. E-mail: lanryadd@yahoo.com, sulaiman.adebayo@eksu.edu.ng
}

Received: September 9, 2014

Accepted: November 7, 2014

Online Published: November 15, 2014

doi:10.5430/jms.v5n4p136

URL: http://dx.doi.org/10.5430/jms.v5n4p136

\begin{abstract}
Customer satisfaction and the commitment of a customer to remain with an organisation may not always be as a result of a positive correlation between these two phenomena. Customers may remain with an organisation depending on the alternatives they have of obtaining the same or similar service elsewhere. This study examined customer satisfaction with three service industries in Nigeria that can be considered as oligopolists (banks, GSM and PHCN). Data were generated from a convenience sample of one hundred and fifty participants based on their response to a customer satisfaction questionnaire. Means and ANOVA statistics were used in the analysis of data. The results of this study showed higher customer satisfaction with banks, followed by GSM and then PHCN. PHCN also had the highest number of customers with low satisfaction compared to the other two industries. Implications of these findings were discussed and recommendations were made.
\end{abstract}

Keywords: customer satisfaction, banks, GSM, PHCN, Nigeria

\section{Introduction}

As firms continue to experience stiff and fierce competition due to increased number of firms providing the same or similar service or product and as customer's behaviours and expectations evolve and change and they become accustomed to patronising multiple outlets, it has become essential for industries to pay attention, understand and acknowledge the customer's concerns in shaping their business strategies. Industries that recognise this trend must know that to remain afloat, prosper and survive is contigent on the continuos innovation of new products and improvement of existing ones that meet current or new needs of customers. Strategically marketing this new and improved products in ways that ensure mass acceptance and a wide reach of a firm's customer base combined with efficient ways of evaluating the effectiveness of such products also contribute to such survival. Hence, to ensure performance excellence, customer's confidence, increased market share and achieve profitable growth; firms must balance their desire to expand rapidly with the need to efficiently serve their customers.

Customer satisfaction is a term central to all positive outcomes that a firm can experience as it carries out its day to day to day activities. The importance of customer satisfaction is emphasised by Zairi (2000):

"Customers are the purpose of what we do and rather than depending

on us, we very much depend on them. The customer is not the source

of a problem; we should not perhaps make that customer should go

away because our future and our security will be put in jeopardy".

Different scholars have tried in different ways to put meaning to the concept of customer satisfaction. Westbrook, (1980) defined customer satisfaction as a person's subjective favourable evaluation/experience of a product. Anderson, Fornell and Mazvancheryl, (2004) sees customer satisfaction as the customer's evaluation that results from the customer's total purchase and consumption experience with a product or service overtime. More broadly, Saha and Zhao (2005) define customer satisfaction as resulting from the combination of the customer's perception, evaluat8ion and psychological response to their experience of service or products, and their cognitive and affective evaluation through comparison of the customer's personally defined standards and perceived service or product value. Similarly, customer satisfaction may be viewed as the overall attitude towards a service or product provider or 
an emotional reaction when the customer's experience does not meet their expectations regarding the fulfillment of a need (Hansemark \& Albinsson, 2004). All these definitions emphasise the importance of customer satisfaction, its subjective nature and the need for firms to take it seriously.

\section{Theoretical Background}

That customer's experience of service results in their satisfaction or dissatisfaction as well as positive or negative outcome for the firm has its basis in the propositions of many theories that focus on how relationship maintenance is a function of whether the parties in a relationship are satisfied with what they give (cost, effort) and receive (rewards, outcomes) in that relationship. Such theories include the effort-reward imbalance model (ERI) by Siegrist (1996), equity theory by (Adam, 1963) and the social exchange theory (SET) by Thibaut and Kellly (1959). However, the SET best explains the firm-customer relationship because it also addresses all the parameters with which a customer may decide to remain with or switch firms. Specifically it asserts that in a relationship each party compares reward with cost of being in such a relationship and also compares reward with what they can get if in a similar relationship with another party, this the authors called comparison level for alternatives. When one of the parties in a relationship believes that better rewards can be obtained elsewhere, the commitment to remain in that relationship is affected. Hence, in a firm-customer relationship if the customer believes that better quality of service can be obtained elsewhere, he or she might decide to switch firms.

\section{Rationale for the Study}

A decision that can result from comparison level for alternatives is repurchase intention; the intention to purchase a service or product again. Indeed some studies have found a relationship between perceived service quality and customer behavioural intention (Park, Robertson, \& Wu, 2006; Saha \& Theingi, 2009). Also, satisfied customers are likely to recommend to five or six people while dissatisfied ones have the tendency to share their experiences to ten other people (Anton, 1996; Athanassopoulos, 2000; Hoyer \& MacInns 2001; La Barbera \& Mazursky 1983; Zairi, 2000).

That satisfaction influences repurchase intention implies that whenever a customer buys a product or service and intends to patronise such service/product again in the future, it means that he or she was satisfied with his/her prior service or product experience. However, running to such conclusions can be erroneous because in cases where customers do not have or are limited in the alternatives they have of service/product provider, their repurchase intention may not be due to satisfaction with service/product but rather due to lack of alternatives. This is in line with the assertions of Homburg and Giering (2001); Jackson, Sullivan, Harnish and Hodge (1996); Platow, Harley, Hunter and Banning (1997) that customer's behaviours and attitudes are greatly influenced by situational factors; in this case "a situation of lack of or limited alternatives". Hence, when a firm's customer base is used as an index of how well the firm is performing, it is important to always take into consideration, if or the extent to which customers have the choice of seeking services/product elsewhere.

Although the studies on customer satisfaction constitute a large part of the literature on consumer behaviour, however, few studies have paid attention to customer satisfaction with firms that are oligopolist. The purpose of this research is to understand customer satisfaction with the performance of the service industries in Nigeria while focusing on telecommunication industry, power industry and banking industry.

This research focused on these industries since they are typical examples of oligopolists in the service sector of Nigeria and their customers have limited or no alternatives than to patronise them. They are service industries for which there is minimal or no competition for their services. Nigerians only have one source of electricity supply which is Power Holding Company of Nigeria $(\mathrm{PHCN})$, the only other alternative is an electricity generator. For telecommunication services (GSM) Nigerians only have four choices (MTN, AIRTEL, GLO and ETISALAT). Regarding banks, although Nigerians have close to thirty banks, however, the extent to which banks are available in locations that are most convenient to one is a major factor in the choice of the banks that a customer chooses to patronise (KPMG Nigeria, 2013; Ovia, 2002). Not all banks have their branches or services in every part of the country; hence, a customer's choice is limited by the banks that are most available to them in terms of proximity and convenience.

In a competitive environment, people generally do not continue to purchase products toward which they are ambivalent or hold negative evaluations (Howard, 1977). However, in a less competitive environment, the importance of customer satisfaction decreases as the firms have increased bargaining power. For instance, Gilbert, Nicholls and Roslow (1999) compared customer satisfaction of two types of government customers: captives (customers that have limited choice) and direct buyers (customers that have greater choice), they found that greater 
customer satisfaction was experienced by direct buyers. Thus, it can be hypothesised that satisfaction will be lower for services for which customers have limited or no alternatives compared to those for which they have more alternatives. The following hypotheses were tested:

1. Customer satisfaction with banks will be higher than that of GSM and that of GSM will be higher than that of PHCN.

2. PHCN will have the largest number of customers with low satisfaction followed by GSM and then banks.

\section{Research Method}

This study collected data from a convenient sample of one hundred and fifty participants on their satisfaction with services received from banks, GSM and PHCN within the last six months. The data were collected using the Client Satisfaction Questionnaire version 8 (CSQ 8) developed by Larsen, Attkisson, Hargreaves and Nguyen (1979).

\section{Result}

Table 1

\begin{tabular}{lll}
\hline & \multicolumn{2}{c}{ Demographic characteristics of participants } \\
\hline Sex & Age & Education \\
\hline Males $97(64.7 \%)$ & 15-24 years 7 $(4.7 \%)$ & Pry Sch/SSCE 5 $(3.3 \%)$ \\
Females 53(35.3\%) & 25-34 years 71 $(47.3 \%)$ & B.SC/OND/HND 106 (70.7\%) \\
& 35-44 years 63 $(42 \%)$ & \\
& 43-56years 9 $(6 \%)$ & Postgraduate 39 $(26 \%)$ \\
\hline
\end{tabular}

Table 2. Table of means and standard deviation of all participants by satisfaction with banks, GSM and PHCN

\begin{tabular}{llll}
\hline & N & Mean & Std \\
\hline Customer satisfaction with banks & 150 & 23.7533 & 5.1121 \\
Customer satisfaction with GSM & 150 & 19.5267 & 4.3189 \\
Customer satisfaction with PHCN & 150 & 12.4200 & 3.9954 \\
Total & 450 & 18.5667 & 6.4867 \\
\hline
\end{tabular}

Table 3. One-way ANOVA table showing the differences in customer satisfaction with banks, GSM and PHCN

\begin{tabular}{lllll}
\hline & Sum of squares & Df & Means square & F \\
\hline Between groups & 9840.693 & 2 & 4920.347 & $242.979^{* * *}$ \\
Within groups & 9051.807 & 447 & 20.250 & \\
Total & 18892.500 & 449 & & \\
\hline
\end{tabular}

$* * * \mathrm{P}<0.0001$ 
Table 4. Table of means and standard deviation showing customer satisfaction (low and high) with banks, GSM and PHCN

\begin{tabular}{|c|c|c|c|}
\hline a. Customer satisfaction with banks & $\mathbf{N}$ & Mean & Std \\
\hline Low satisfaction & 68 & 19.1765 & 3.0466 \\
\hline High satisfaction & 82 & 27.5488 & 2.8681 \\
\hline Total & 150 & 23.7533 & 5.1121 \\
\hline b. Customer satisfaction with GSM & $\mathbf{N}$ & Mean & Std \\
\hline Low satisfaction & 79 & 16.2025 & 2.6379 \\
\hline High satisfaction & 71 & 23.2254 & 2.3676 \\
\hline Total & 150 & 19.5267 & 4.3189 \\
\hline c. Customer satisfaction with $\mathrm{PHCN}$ & $\mathbf{N}$ & Mean & Std \\
\hline Low satisfaction & 135 & 11.4370 & 2.7714 \\
\hline High satisfaction & 15 & 21.2667 & 1.7915 \\
\hline Total & 150 & 12.4200 & 3.9954 \\
\hline
\end{tabular}

Note: grouping into low satisfaction and high satisfaction for each industry is a function of scoring below and above the mean customer satisfaction score in each of them.

\section{Findings and Discussion}

The first hypothesis which stated that customer satisfaction with banks (mean=23.7533, table 2) will be higher than that of GSM (mean=19.5267 table 2) and that of GSM will be higher than that of PHCN (mean=12.4200, table 2) was supported $(F=242.979 p<0.001$, table 3). Participants reported higher satisfaction with bank service followed by GSM service and PHCN service. Post-hoc analysis using Scheffe test also showed the difference to be significant among the three industries. The second hypothesis was also supported; PHCN had the highest number of customers with low satisfaction ( $\mathrm{N}=135$, table $4 \mathrm{c})$ followed by GSM $(\mathrm{N}=79$, table $4 \mathrm{~b})$ and then banks $(\mathrm{N}=68$, table $4 \mathrm{a})$. The lower satisfaction level with PHCN services compared to banks and GSM services lends credence to Howard's, (1977) assertion that the importance of customer satisfaction diminishes when a firm has increased bargaining power and also to Gilbert et al., (1999) finding of lower satisfaction among government customers with limited alternatives. The lower satisfaction with PHCN services is also not surprising given the recent erratic electricity supply in the country.

\section{Conclusions}

The findings of this research showed that of the three industries studied, PHCN emerged as the industry with the lowest ranking in customer satisfaction followed by GSM and banks. Result showed that customer satisfactions vary across the three industries and according to how such industries offer alternative sources of service; with customer satisfaction corresponding with increasing number of service provider within the industry. Although this outcome do not definitively points towards customer satisfaction being a function of the number of alternative sources of service available to the customer, however, it suggests some sort of relationship. The specifics mechanism of how this relationship works can be explored by other studies.

The satisfaction with banks and GSM performance cannot be said to be optimum as revealed by the result of this study and some other studies such as (KPMG Africa, 2013; KPMG Nigeria, 2013). For instance, KPMG, Africa (2013) found that only ten banks in Nigeria ranked above the country's industry average customer satisfaction index score while KPMG Nigeria (2013) found a marginal decline in overall Customer Satisfaction Index (CSI) from the previous year. GSM's performance is also performing below expectations. For instance, Adegoke and Babalola's (2011) study concluded that the performance of GSM networks in Nigeria is still a far cry from expectations of the consumers. What is peculiar to both these industries is that although their performance is not excellent, they still provide alternatives for the customer to choose the service provider that best suit their own needs. However, such is not obtainable with the power industry that offers just PHCN to Nigerians. PHCN is bedeviled with various problems and customer satisfaction with the power industry is low (Usman, 2013). Perhaps, dissatisfaction with the industry is exacerbated by the lack of alternative which forces Nigerians to continue to patronise a service provider with whom 
they are dissatisfied or results to using electricity generating set which can be capital-intensive for individuals and corporations.

A good question is, if there were multiple electricity suppliers in Nigeria other than PHCN, would the government have found a panacea for the electricity problems in Nigeria?. Will PHCN get away with rendering poor quality service?

\section{Recommendations}

Providing Nigerians with good services and a good value for their money should be important to the service industries in this study and indeed to all industries in general. The three industries in this study all had high number of customers with lower satisfaction; the government of Nigeria should put in organs that will monitor these industries to ensure that Nigerians are not made to endure poor and shoddy services, organs that are already in place should be enforced to carry out their duties to the populace.

However, since service failures cannot but occur due to both human and non-human errors, such failures to perform according to customer's expectations inevitably lead to customer dissatisfaction. Such dissatisfaction can bring about negative word of mouth about the services of such firms. It is therefore important that service industries take effort to listen, attend to and resolve customer complaints promptly. It has been recognised that once a service failure occurs, it becomes crucial that service recovery; which is the action taken by the service provider to seek out dissatisfaction in response to poor service quality, be effectively carried out to reduce the damage in relationship and to pacify the dissatisfied customer.

Nigerians are also said to be culturally resilient. They have a reputation of being tenacious, undaunted and hopeful; this extends to how they react to the quality of service they receive. Nigerians may complain about the injustice done to them in terms of receiving value for their money in the comfort of their homes, however, do they attempt to do anything substantial about it? people will rather suffer in silence which has made Nigerians be nicknamed "suffering and smiling". Nigerians need to be upfront and outspoken when it comes to demanding value for their money, they need to know that they have to make their dissatisfaction with products/service known to their providers; one can hardly see Nigerians drop comments into suggestion boxes provided in most organisation nor see them call the customer-care lines provided on some products to lodge a complaint. For service/product providers to sit up and treat their customers better, Nigerians also need to sit up and make effort in ensuring that they are treated better. When the masses ensure that appropriate authorities are aware of their grievances, a positive step has been taken in the road to eradicating substandard services in the country.

This study is not without limitations. First the findings of the study are based on data collected from a convenience sample of only one hundred and fifty participants who all reside in Lagos state. This affects the generalisability of the result of the study to the larger population. As with all self-report studies, self-reports measures are prone to social desirability and recall bias. Future researches should consider a larger and better representative sample and also further explore how limited alternatives in choice of service providers may influence customer satisfaction.

\section{Referrences}

Adams, S. J. (1963). Toward an understanding of Inequity. Journal of Abnormal and Social Psychology, 67, 422-436. http://dx.doi.org/10.1037/h0040968

Adegoke A. S., \& Babalola I. T. (2011). Quality of service analysis of GSM telephone system in Nigeria. American Journal of Scientific and Industrial Research. http://dx.doi.org/10.5251/ajsir.2011.2.5.707.712

Anderson, E. W., Fornell, C., \& Mazvancheryl, S. K. (2004). Customer satisfaction and shareholder value. Journal of Marketing, 68, 172-185. http://dx.doi.org/10.1509/jmkg.68.4.172.42723

Anton, J. (1996). Customer relationship management: Making hard decisions with soft numbers. Upper Saddle River: Prentice Hall.

Athanassopoulos, A. D. (2000). Customer satisfaction cues to support market segmentation and explain switching behaviour. Journal of Business Research, 47(3), 191-207. http://dx.doi.org/10.1016/S0148-2963(98)00060-5

Gilbert, G. R., Nicholls, J. A. F., \& Roslow, S. (1999). Measuring public sector customer service satisfaction. The Public Manager, 26(4), 21-25.

Hansemark, O. C., \& Albinson, M. (2004). Customer satisfaction and retention: The experiences of individual employees. Managing Service Quality, 14(1), 40-57. http://dx.doi.org/10.1108/09604520410513668

Homburg, C., \& Giering, A. (2001). Personal characteristics as moderators of the relationship between customer 
satisfaction and loyalty: An empirical analysis. Psychology and Marketing, 18(1), 43-66. http://dx.doi.org/10.1002/1520-6793(200101)18:1<43::AID-MAR3>3.0.CO;2-I

Howard, J. A. (1977). Consumer behaviour: Application of theory. New York: McGraw-Hill. http://dx.doi.org/10.1163/156853977X00135

Hoyer, W. D., \& MacInnis, D. J. (2001). Consumer behaviour. Houghton Boston: Mifflin Company.

Jackson, L. A., Sullivan, L. A., Harnish, R., \& Hodge, C. N. (1996). Achieving positive social identity: Social mobility, social creativity and permeability of group boundaries. Journal of Personality and Social Psychology, 70, 241-54. http://dx.doi.org/10.1037/0022-3514.70.2.241

KPMG. (2013). Africa banking industry customer satisfaction survey (April, 2013). Nigeria: KPMG.

KPMG. (2013). Banking industry customer satisfaction survey 2013, (June 2013, Issue 7). Nigeria: KPMG.

La Babera, P. A., \& Mazursk, D. (1983). A longitudinal assessment of consumer satisfaction, dissatisfaction: The dynamic aspect of cognitive process. Journal of Marketing Research, 20, 393-404. http://dx.doi.org/10.2307/3151443

Larsen, D. L., Attkisson, C. C., Hargreaves, W. A., \& Nguyen, T. D. (1979). Assessment of client/patient satisfaction: Development of a general scale. Evaluation and Program Planning, 2, 197-207. http://dx.doi.org/10.1016/0149-7189(79)90094-6

Ovia, J. (2002). Payment system and financial innovations. A paper presented at the Annual Policy Conference, November, 2002.

Park, J., Robertson, R., \& Wu, C. (2006). Modelling the impact of airline service quality and marketing variables on passengers' future behavioural intentions. Transportation Planning and Technology, 29(5), 359-381. http://dx.doi.org/10.1080/03081060600917686

Platow, M. J., Harley, K., Hunter, J., \& Banning, P. (1997). Interpreting in-group-favoring allocations in the minimal group paradigm. British Journal of Social Psychology, 36, 107-17. http://dx.doi.org/10.1111/j.2044-8309.1997.tb01121.x

Saha, G.C., \& Theingi (2009). Service quality, satisfaction, and behavioural intentions: A study of low-cost airline carriers in Thailand. Managing Service Quality, 19(3).

Saha, P., \& Zhao, Y. (2006). Relationship between online service quality and customer satisfaction, a study in internet banking, Master Thesis, Lulea University of Technology.

Siegrist, J. (1996). Adverse health effects of high effort-low reward conditions at work. Journal of Occupational Health Psychology, 1, 27-43. http://dx.doi.org/10.1037/1076-8998.1.1.27

Thibaut, J. W., \& Kelly, K. H. (1959). The social psychology of groups. New York, John Wiley and Sons, Inc.

Usman, A. (2013). Determinants of electricity consumers satisfaction in selected electricity distribution zones in Nigeria: Implications for regulatory activities. Journal of Asian Business Strategy, 3(6), 103-124.

Zairi, M. (2000). Managing customer dissatisfaction through effective complaint management system. The TQM Magazine, 12(5), 331-335. http://dx.doi.org/10.1108/09544780010341932 